\title{
PENGARUH KARTU PINTAR IBU TERHADAP PENGETAHUAN IBU DALAM PENATALAKSANAAN DIARE PADA ANAK DI PRE HOSPITAL PADA MASA PANDEMI COVID-19 DI LUBUKLINGGAU
}

\author{
Sapondra Wijaya ${ }^{1}$, Bambang Soewito ${ }^{2}$, Mawadda Umi ${ }^{3}$, Devi Fitria ${ }^{4}$, Vina Ayu Saputri ${ }^{5}$ \\ 1,2 Dosen Program Studi Keperawatan Lubuklinggau Poltekkes Kemenkes Palembang, ${ }^{3,4,5}$ Mahasiswa Program \\ Studi Keperawatan Lubuklinggau Poltekkes Kemenkes Palembang \\ Alamat korespondensi: ondra@ poltekkespalembang.ac.id
}

\begin{abstract}
Abstrak
Pembatasan kegiatan aktifitas di luar rumah diberlakukan pada masa pandemic Covid-19 untuk meminimalkan penyebaran virus Covid-19. Salah satu kegiatan luar rumah yang sering dilakukan adalah melakukan pengobatan di fasilitas kesehatan. Anak merupakan golongan usia yang rentan terhadap paparan penyakit. Banyak penyakit yang sering terjadi pada anak, termasuk diare. Salah satu tempat yang rawan terjadi penularan penyakit adalah di fasilitas kesehatan, sedangkan anak diare cenderung dibawa oleh orang tua ke fasilitas kesehatan. Oleh karena itu, perlu adanya sosialisasi tentang penanganan diare fase pre hospital atau di rumah, sehingga anak bisa dirawat di rumah terlebih dahulu jika memang kondisinya memungkinkan. Tujuan dari penelitian ini adalah untuk mengetahui pengaruh Kartu Pintar Ibu yang merupakan penyederhanaan dari buku Manajemen Terpadu Bayi Sakit (MTBS), terhadap pengetahuan dalam penatalaksanaan diare pada anak fase pre hospital. Penelitian ini menggunakan rancangan quasi eksperimen dengan pendekatan pre dan post test dengan tehnik purposive sampling pada $30 \mathrm{ibu}$. Pengetahuan ibu diukur dari pengetahuan tentang diare dan penatalaksanaannya. Hasil analisa data menggunakan t-Tes berpasangan mendapatkan hasil bahwa ada pengaruh yang signifikan dari Kartu Pintar Ibu terhadap pengetahuan ibu dalam penatalaksanaan diare anak di rumah dengan nilai $\mathrm{p}=0,000$. Hal ini berarti Kartu Pintar Ibu bisa meningkatkan pengetahuan ibu dalam penatalaksanaan diare anak fase pre hospital. Hasil ini diharapkan Kartu Pintar Ibu dapat menjadi rujukan dalam peningkatan pengetahuan ibu, dan meminimalkan pengobatan di fasilitas kesehatan yang kurang tepat yang dapat beresiko terjadi penularan Covid-19.
\end{abstract}

\section{Kata Kunci: Anak, Diare, Kartu Pintar Ibu, Pre Hospital, Covid-19}

\begin{abstract}
Restrictions on activities outside the home were imposed during the Covid-19 pandemic to minimize the spread of the Covid-19 virus. One of the activities outside the home that is often carried out is taking medication at a health facility. Children are an age group that is vulnerable to disease exposure. Many diseases that often occur in children, including diarrhea. One of the places prone to disease transmission is in health facilities, while children with diarrhea tend to be taken by their parents to health facilities. Therefore, there is a need for socialization about the handling of diarrhea in the pre-hospital phase or at home, so that children can be treated at home first if the conditions allow. The purpose of this study was to determine the effect of the Mother's Smart Card, which is a simplification of the MTBS book, on knowledge in managing diarrhea in children in the pre-hospital phase. This study used a quasi-experimental design with a pre and post test approach with purposive sampling technique on 30 mothers. Maternal knowledge is measured from knowledge of diarrhea and its management. The results of data analysis using the paired t-test showed that there was a significant effect of the Mother's Smart Card on the mother's knowledge in managing children's diarrhea at home with a value of $p=0.000$. This means that the Mother's Smart Card can increase maternal knowledge in the management of pre-hospital phase children's diarrhea. This result is expected that the Mother's Smart Card can be a reference in increasing maternal knowledge, and minimizing treatment in inappropriate health facilities that can be at risk of Covid-19 transmission.
\end{abstract}

Keywords: Children, Covid-19, Diarrhea, Mommy Smart Card, Pre Hospital 


\section{PENDAHULUAN}

Virus Corona atau yang dikenal dengan sebutan Covid-19 pertama kali muncul di China pada tahun 2019 dan menyebar keseluruh dunia dengan sangat cepat serta memiliki Morbiditas dan mortalitas yang signifikan. Tingkat kematian yang disebabkan oleh Covid-19 adalah sekitar $4.8 \%$ (Meihartati et al, 2020). Kondisi ini menyebabkan World Health Organization (WHO) mendeklarasikan sebagai masa pandemi Covid-19 pada tanggal 12 Maret 2020 (Setyawan et al, 2020). Prevalensi kasus Covid-19 di Dunia pertengahan September 2020 mencapai 29.155.581 dan kematian tercatat 926.544 jiwa dengan tersebar ke 216 negara sehingga Case Fatality Rate sebesar 3,17\% (WHO, 2020). Informasi yang marak ini membuat terjadi kecemasan di masyarakat (Sari, 2020).

Banyak upaya yang sudah dilakukan untuk menekan penyebaran virus Covid-19. Di Indonesia jamak dilaksanakan peraturan 3M (Memakai Masker, Menjaga Jarak, Mencuci Tangan), penerapat Protokol Kesehatan di tempat ramai, sampai Pembatasan Sosial Berskala Besar (PSBB). Salah satu yang dianjurkan dalam PSBB adalah mengurangi kegiatan di luar rumah. Melakukan pembatasan sosial merupakan langkah yang dianggap paling efektif agar tidak terjangkit Covid-19 (Widodo, 2020).

Salah satu kegiatan di luar rumah yang sering dilakukan oleh masyarakat adalah mendatangi fasilitas kesehatan untuk berobat. Rumah Sakit merupakan tempat terjadinya infeksi nosocomial Covid-19 baik yang ditularkan penderita ataupun staf rumah sakit tersebut (Hidayani, 2020). Sehingga untuk memperoleh layanan kesehatanpun, sangat beresiko tertular virus Covid-19. Usia rentan terhadap paparan penyakit adalah anak-anak dan lansia.

Usia balita digolongkan oleh para ahli sebagai tahapan perkembangan anak yang cukup rentan terhadap berbagai penyakit, termasuk penyakit yang disebabkan oleh kekurangan atau kelebihan asupan nutrisi jenis tertentu (Lase, 2019). Covid-19 yang menyerang anak-anak, orang tua, individu dengan gangguan sistem kekebalan tubuh, dan individu yang memiliki komorbiditas lebih rentan menjadi sakit dan memiliki gejala penyakit yang lebih berat (Heymann \& Shindo, 2020).

Salah satu penyakit yang sering terjadi pada anak adalah diare. Masalah diare di Negara berkembang seperti di Indonesia tingkat morbiditas dan mortalitas-nya yang masih tinggi (Lase, 2019).

Diare adalah kondisi dimana individu mengalami buang air besar dengan frekuensi sebanyak 3 atau lebih per hari. Hal ini merupakan gejala infeksi pencernaan, yang disebabkan oleh berbagai bakteri, organisme, virus dan parasit. Diare yang parah menyebabkan kehilangan cairan, dan dapat mengancam nyawa, terutama pada anak-anak (WHO, 2013)

Pada kondisi normal sebelum pandemi, orangtua bisa dengan segera membawa anaknya ke fasilitas kesehatan pada saat terjadi diare, baik diare dengan dehidrasi ringan, sedang atau berat. Di situasi pandemic ini, sangat beresiko tertular Covid-19 jika mendatangi fasiltas kesehatan, walaupun tujuannya adalah memperoleh pelayanan kesehatan. Apalagi ada stigma negative terhadap pasien Covid-19. Stigma telah menyebabkan ketakutan, kekhawatiran berlebihan di masyarakat akan tertular COVID-19 (Agung, 2020).

Sehingga diharapkan ketika seorang ibu mebawa anaknya yang diare ke fasilitas kesehatan, adalah benar-benar kondisi anaknya memang sudah sepantasnya dibawa ke fasilitas kesehatan. Kondisi diare seperti apa yang layak untuk dibawa ke fasilitas kesehatan sudah tergambar di buku Manajemen Terpadu Bayi Sakit.

Penelitian ini berupaya memberikan pengetahuan baru kepada ibu tentang bagaimana penatalaksanaan anak diare di rumah pada kondisi yang memang layak untuk dirawat di rumah sesuai MTBS. Peneliti berupaya menyederhanakan MTBS bagian Diare untuk mempermudah ibu memahami tentang masalah diare dan penatalaksanaannya. 
Sebelumnya Perangin-angin (2016) mengembangkan Kartu Sehat bagi siswa kelas VIII di SMP Islam Al-Madina Kota semarang dengan tujuan meningkatkan pengetahuan tentang pendidikan kesehatan siswa. Penelitian sebelumnya tentang peningkatan pengetahuan ibu belum menggunakan media yang sederhana, kebanyakan hanya menggunakan materi yang di paparkan atau pembuatan leaflet. Penelitian ini mengembangkan sendiri media dari hasil penyederhanaan MTBS. Pengembangan yang dilakukan menghasilkan media yang kami sebut Kartu Pintar Ibu.

Sebelumnya peneliti belum pernah melihat Kartu Pintar Ibu penyederhanaan dari MTBS untuk meningkatkan pengetahuan ibu dalam penanganan anak diare pada fase pre hospital.

Tujuan dari penelitian ini untuk mengetahui apakah ada pengaruh penggunaan Kartu Pintar Ibu terhadap pengetahuan ibu tentang penatalaksanaan diare pada fase pre hospital.

\section{METODE PENELITIAN}

Penelitian ini merupakan penelitian kuantitatif dengan rancangan quasi experiment dengan pendekatan pre and post test design. Kelompok eksperimen pada penelitian ini diberikan perlakuan berupa metode pendidikan kesehatan dengan menggunakan Kartu Pintar Ibu.

Pengambilan sampel pada penelitian ini menggunakan tehnik purposive sampling dengan sampel berjumlah $30 \mathrm{ibu}$.

Kriteria inklusi sampel penelitian ini adalah ibu dengan balita yang pernah mengalami diare dan pernah juga membawa anaknya ke fasilitas kesehatan pada saat diare. Sedangkan kriteria inklusi sampel penelitian ini adalah memiliki keterbatasan fisik, tidak bisa membaca, dan berusia lanjut.

Data dikumpulkan dengan kuesioner yang dilakukan dua kali, pre dan post pendidikan kesehatan menggunakan Kartu Pintar Ibu. Analisis data menggunakan t-Tes berpasangan dengan menggunakan skala ordinal. Analisis data menggunakan bantuan program SPSS Ver.22 dengan tingkat kepercayaan $96 \%(\mathrm{p} \leq 0,005)$.

\section{HASIL PENELITIAN}

Berikut ini merupakan hasil penelitian mengenai karakteristik responden.

Tabel 1. Karakteristik Responden

\begin{tabular}{llcc}
\hline \multirow{2}{*}{ Karakteristik Responden } & \multicolumn{2}{c}{ Kelingi } \\
\cline { 2 - 4 } & & Freq & \% \\
\hline \multirow{3}{*}{ Umur } & $21-30$ tahun & 8 & $27 \%$ \\
\cline { 2 - 4 } & $31-40$ tahun & 19 & $63 \%$ \\
\cline { 2 - 4 } & $41-50$ tahun & 3 & $10 \%$ \\
\hline \multirow{4}{*}{ Pendidikan } & SMP & 3 & $10 \%$ \\
\cline { 2 - 4 } & SMA & 12 & $40 \%$ \\
\cline { 2 - 4 } & D3 & 7 & $23 \%$ \\
\cline { 2 - 4 } & S1 & 8 & $27 \%$ \\
\hline
\end{tabular}

Hasil penelitian menunjukkan responden paling banyak adalah yang berusia 31-40 tahun (63\%). Tingkat pendidikan mayoritas responden adalah SMA $(40 \%)$. 
Tabel 2. Perbandingan Rata-rata nilai pengetahuan

\begin{tabular}{llc}
\hline No & \multicolumn{1}{c}{ Variabel } & Rata-Rata Nilai \\
\hline 1. & $\begin{array}{l}\text { Pengetahuan sebelum dilakukan pendidikan kesehatan } \\
\text { dengan Kartu Pintar Ibu }\end{array}$ & 56.27 \\
\hline 2. & $\begin{array}{l}\text { Pengetahuan sesudah dilakukan pendidikan kesehatan } \\
\text { dengan Kartu Pintar Ibu }\end{array}$ & 74.00 \\
\hline
\end{tabular}

Hasil penelitian menunjukkan bahwa rata-rata nilai pengetahuan ibu sebelum dan sesudah diberi pendidikan kesehatan dengan Kartu Pintar Ibu. Sebelum diberi pendidikan kesehatan rata-rata nilai pengetahuan dari 30 orang adalah 56.27, sementara setelah diberi pendidikan kesehatan rata-rata nilai pengetahuan adalah sebesar 74.00. Hal ini mengindikasikan bahwa terdapat peningkatan pengetahuan masyarakat terhadap masalah Diare yang dialami anak di rumah, dimulai dari tanda gejala, penanganan awal serta tindakan yang harus dilakukan berdasarkan kondisi anak.

Tabel 3. Hasil Uji t berpasangan

\begin{tabular}{cccc}
\hline Variabel & t & p-value & Keterangan \\
\hline $\begin{array}{l}\text { Nilai Rata-Rata Pengetahuan Sebelum } \\
\text { dan Sesudah penyuluhan dan pelatihan }\end{array}$ & -12.486 & 0.000 & Signifikan \\
\hline
\end{tabular}

Pada tabel diatas diperoleh nilai $\mathrm{t}$ hitung adalah sebesar -12.486 dengan nilai signifikan 0.000 . Karena sig $<0.05$, artinya rata-rata nilai pengetahuan sebelum dan sesudah diberi pendidikan kesehatan dengan Kartu Pintar Ibu berbeda. Dengan demikian dapat dinyatakan bahwa pendidikan kesehatan dengan Kartu Pintar Ibu mempengaruhi nilai pengetahuan ibu dengan kata lain bahwa adanya pendidikan kesehatan dengan Kartu Pintar Ibu mengenai masalah diare anak dapat meningkatkan pengetahuan ibu terhadap masalah Diare yang dialami anak di rumah, dimulai dari tanda gejala penanganan awal serta tindakan yang harus dilakukan berdasarkan kondisi anak.

\section{PEMBAHASAN}

Berdasarkan hasil uji statistik ada peningkatan rata-rata nilai pengetahuan ibu setelah diberikan pendidikan kesehatan menggunakan Kartu Pintar Ibu. Fakta ini sesuai dengan teori bahwa tujuan dari pendidikan kesehatan adalah terjadinya perubahan pengetahuan, sikap dan tingkah laku individu, keluarga, kelompok khusus, dan masyarakat dalam membina serta memelihara perilaku hidup sehat serta berperan aktif dalam upaya mewujudkan derajat kesehatan yang optimal (Nursalam \& Effendi, 2008).

Perubahan di atas terjadi setelah dilakukan pendidikan dan pelatihan menggunakan Kartu Pintar Ibu, tujuan utama dari pendidikan kesehatan ini adalah memberikan pengetahuan dasar kepada ibu-ibu tentang masalah diare, dan bagaimana cara merespon keadaan anak diare di rumah atau fase pre hospital sesuai dengan tingkat keparahan anak. Pate, et al, (2016) mengatakan ada peningkatan pengetahuan, kepercayaan diri, serta pengertian tentang peran dan tanggung jawab setelah diberikan pelatihan dan penyuluhan.

Dalam menjaga kesehatan seseorang, factor perilaku sangat berpengaruh. Menurut B. Bloom, ada tiga aspek dari perilaku, yaitu pengetahuan, sikap, dan tindakan (Notoatmodjo, 2014). Sehingga peningkatan pengetahuan ibu sangat penting terhadap kesehatan anak. 
Peningkatan pengetahuan ini diharapkan akan membuat ibu menjadi lebih faham waktu yang tepat untuk mengunjungi fasilitas kesehatan saat anak terkena diare. Pengetahuan sebagai parameter keadaan sosial dapat sangat menentukan kesehatan masyarakat (Widyastuti, 2012). Masyarakat yang memiliki pengetahuan baik juga memiliki sikap dan perilaku yang baik pula (Suprayitno, et al. 2020). Pemberian pengetahuan yang spesifik, valid, dan tepat sasaran dapat meningkatkan perilaku usaha pencegahan masyarakat terhadap infeksi Covid-19 (Maudy \& Syakurah, 2020).

Semakin luas pengetahan ibu terhadap kesehatan anak terutama diare, akan semakin tepat penatalaksan diare anak pada fase pre hospital. Harapan akhirnya adalah kunjungan ke fasilitas kesehatan yang kurang tepat menurun, karena akan sangat beresiko tertular Covid-19. Rumah Sakit merupakan tempat terjadinya infeksi nosocomial Covid-19 baik yang ditularkan penderita ataupun staf rumah sakit tersebut (Hidayani, 2020).

Dalam penatalaksanaan diare menurut MTBS, pada kondisi ringan dan sedang anak tidak perlu dibawa ke fasilitas kesehatan, bisa dirawat dirumah sendiri,. Dengan meningkatnya pengetahuan ibu dalam penanganan diare fase pre hospital, maka anak akan semakin terhindar dari infeksi Covid-19 yang bisa saja terjadi di fasilitas kesahatan. Peran orang tua selama masa isolasi social adalah hal terpenting bagi anak (Pradana et al, 2020).

Semua peserta pelatihan adalah masyarakat sipil dengan 50\% tingkat pendidikan SMA kebawah. Data diatas menunjukkan Kartu Pintar Ibu ini sangat sederhana, dan ini adalah bentuk penyederhanaan dari Buku MTBS. Kartu Pintar Ibu ini sangat sederhana dan sangat mudah dimengerti oleh masyarakat. Dalam proses pembelajaran salah satu cara agar siswa tertarik dalam proses pembelajaran penjasorkes adalah dengan adanya variasi atau modifikasi (Perangin-angin, 2016).
Dalam bentuk aslinya, MTBS sangat susah untuk dimengerti masyarakat awam. Disini peneliti melakukan inovasi untuk menyederhanakan MTBS khususnya bagian Diare agar dapat digunakan seharihari dan dapat meningkatkan pengetahuan ibu tentang diare dan penatalaksanaannya. Esensi modifikasi adalah menganalisi sekaligus mengembangkan materi pelajaran dengan cara meruntunnya dalam bentuk aktivitas belajar yang potensial, sehingga dapat memperlancar siswa dalam belajarnya (Perangin-angin, 2016).

\section{SIMPULAN DAN SARAN}

Berdasarkan hasil analisa dan pembahasan dapat disimpulkan bahwa ada pengaruh yang positif terkait penggunaan Kartu Pintar Ibu pengetahuan Ibu tentang bagaimana merespon masalah diare anak di rumah. Hasil ini juga menunjukkan bahwa Kartu Pintar Ibu efektif untuk digunakan sebagai media pembelajaran masyarakat dalam usaha meningkatkan pengetahuan ibu dalam penatalaksanaan masalah diare di rumah. Peneliti selanjutnya diharapkan dapat meneliti lebih banyak variabel lagi, seperti variabel pengambilan keputusan dan sikap. Saran peneliti juga diharapkan Kartu Pintar Ibu ini dapat diaplikasikan menjadi sebuah aplikasi digital.

\section{DAFTAR PUSTAKA}

Agung, Ivan Muhammad. (2020). Memahami Pandemi COVID-19 dalam Perspektif Psikologi Sosial. Psikobuletin: Buletin Ilmiah Psikologi. Vol. 1, No. 2, Mei, 2020 (68-84). e-ISSN : 2720 - 8958. DOI : 10.24014/pib.v1i2.9616

Heymann, D, L., \& Shindo, N. 2020. COVID-19: what is next for public health?. The Lancet, 395(10224):542-5.

Hidayani, W, R. (2020). Faktor Faktor Risiko Yang Berhubungan Dengan COVID 19 : Literature Review. Jurnal Untuk Masyarakat Sehat (JUKMAS) e-ISSN : 2715-7687. Vol. 4, No. 2 Oktober 2020. 
http://ejournal.urindo.ac.id/index.php jukmas

Lase, W, P. (2019). Gambaran Pengetahuan Ibu Tentang Penanganan Diare Pada Balita Di Klinik Sally Tahun 2019. Skripsi. STIKES Santa Elisabeth Medan

Meihartati, T. (2020). Pentingnya Protokol Kesehatan Keluar Masuk Rumah Saat Pandemi Covid-19 Di lingkungan Masyarakat RT 30 Kelurahan Air Hitam, Samarinda, Kalimantan Timur. Pengabdian Masyarakat, 1(2). Retrieved from http://jurnal.itkeswhs.ac.id/index.php /pengmas/article/view/155

Moudy, J dan Syakurah, R, A. (2020). Pengetahuan terkait Usaha Pencegahan Coronavirus Disease (COVID-19) di Indonesia. Higeia Journal Of Public Health Research And Development. HIGEIA 4 (3) (2020).

http://journal.unnes.ac.id/sju/index.p $\underline{\mathrm{hp} / \text { higeia }}$

Notoatmodjo S. 2014. Ilmu Perilaku Kesehatan. 2nd ed. Jakarta: Rineka Cipta.

Nursalam dan Effendi, F. (2008). Pendidikan Dalam Keperawatan. Jakarta: Salemba Medika

Pate, A., Bratberg, J, P., Robertson, C., \& Smith, G. (2016). Evaluation of a Tabletop Emergency Preparedness Exercise for Pharmacy Students. American Journal of Pharmaceutical Education. 80 (3).50

Perangin-angin, L, F., Hanani, S, E., Soenyoto, T. (2016). Pengembangan Media Pembelajaran Pendidikan Kesehatan Melalui Kartu Sehat. Journal of Physical Education, Sport, Health and Recreation (3). http://journal.unnes.ac.id/sju/index.p hp/peshr

Pradana, A, A., Casman., Nur'aini. (2020). Pengaruh Kebijakan Social Distancing Pada Wabah Covid-19 Terhadap Kelompok Rentan Di Indonesia. Jurnal Kebijakan
Kesehatan Indonesia : JKKI, Vol. 09, No. 02 Juni 2020

Sari, Irda. (2020). Analisis Dampak Pandemi Covid- 19 Terhadap Kecemasan Masyarakat : Literature Review. Bina Generasi ; Jurnal Kesehatan. Edisi 12 Volume (1) 2020

Setyawan, A., Purnomo, F, A., Firdaus, J, A., Nugraheni, A. (2020). Sosialisasi Peningkatan Pengetahuan Ibu Hamil dan Balita dalam Pemantauan Secara Mandiri Pada Era Pandemik COVID19 di Kelurahan Ngesrep Semarang. Seminar Nasional Pengabdian Kepada Masyarakat UNDIP 2020. www.semnasppm.undip.ac.id

Suprayitno, E., Rahmawati, R., Ragayasa, A., Pratama, M, Y. (2020). Pengetahuan dan Sikap Masyarakat dalam Pencegahan COVID-19. Journal Of Health Science (Jurnal Ilmu Kesehatan) Vol. V No. II Tahun 2020|68 - 73. https://www.ejournalwiraraja.com/in dex.php/JIK

WHO. (2013). Buku Saku Kesehatan Anak Indonesia di Rumah Sakit. Department of Child and Adolescent Health and Development (CAH)

WHO. (2020). Coronavirus disease (COVID

pandemic.https://who.int. diakses tanggal 18 September 2020

Widodo, Arif. (2020). Pandemi dan Bentuk Diskriminasi Baru: Sebuah Kritik Terhadap Perilaku Masyarakat Dalam Menghadapi Wabah Covid19. Jurnal Pendidikan Sosial Keberagaman. Print-ISSN 23554622 Online-ISSN 2622-9021. Vol. 7, No. 2, Oktober-Maret 2020, hh. 149-159

Widyastuti, T. (2012). Faktor-Faktor Yang Berhubungan Dengan Perilaku Ibu Terhadap Pencegahan Diare Pada Anak Balita Di Wilayah Kerja Puekesmas 4 Ulu Palembang Tahun 2012. Skripsi. Universitas Muhammadiyah Palembang 